Article

\title{
Incorporating Air Quality Improvement at a Local Level into Climate Policy in the Transport Sector: A Case Study in Bandung City, Indonesia
}

\author{
Helmi Gunawan ${ }^{1,2, *} \mathbb{D}$, Hans Bressers ${ }^{1}$, Nthabiseng Mohlakoana ${ }^{1}$ and Thomas Hoppe ${ }^{3}$ \\ 1 Department of Governance and Technology of Sustainability (CSTM),Faculty of Behavioural, Management, \\ and Social Science, University of Twente, 7522 NB Enschede, The Netherlands; \\ j.t.a.bressers@utwente.nl (H.B.); n.mohlakoana@utwente.nl (N.M.) \\ 2 Graduate School of Environmental Science, Padjadjaran University, Jawa Barat 45363, Indonesia \\ 3 Department of Multi-Actor Systems, Policy, Organisation, Law and Gaming, Faculty of Technology, Policy \\ and Management, TU Delft, 2628 CD Delft, The Netherlands; t.hoppe@tudelft.nl \\ * Correspondence: h.gunawan@utwente.nl; Tel.: +62-2208-1661-0066
}

Received: 31 March 2017; Accepted: 21 June 2017; Published: 24 June 2017

\begin{abstract}
Climate policy has a strong influence on policy processes at national levels in Indonesia, while other policies with a focus on air quality improvement are being implemented at local levels. Indonesia as a developing country has committed to reducing greenhouse gas (GHG) emissions by 29 percent by the year 2030. This calls into question the extent to which cities and local governments can cope with the challenges of climate change mitigation. The purpose of the research is to find out the extent to which local air pollution reduction policies can contribute to the climate change mitigation program. The research design involved an empirical case study on governance and policy relevant to climate change efforts to lower GHG in Bandung City, Indonesia. The study evaluated the air quality improvement and the climate change mitigation programs using the actor-based framework of the Contextual Interaction Theory (CIT). The governance and stakeholder characteristic of climate change mitigation were also analysed using the structural context part of the CIT framework. The result shows that air quality improvement policy is implemented separately from climate policy; the latter operates at the national level and the former at the local level. By looking at the actor interaction analysis, the study concludes that a more holistic environmental policy approach would be more efficient at reducing local air pollution and contributing to the mitigation of climate change.
\end{abstract}

Keywords: air quality improvement; climate change mitigation; local government; contextual interaction theory; co-benefit goals

\section{Introduction}

Global climate change, environmental degradation, poverty, and the lack of availability of water and food due to population density pressures are factors that magnify disasters. These should be avoided, mitigated and thoroughly managed, particularly in developing countries [1-3]. Rapid population growth and broadening of human activities have had a detrimental effect on the climate because of anthropogenic emissions sources.

Transportation is one sector that emits greenhouse gases (GHGs) and contributes significantly to climate change and air pollution. Increasing motor vehicle use in cities, particularly in developing countries, increases fuel consumption and, thus, GHGs emissions. It is difficult to reduce these $\mathrm{CO}_{2}$ emissions since so many primary economic activities rely on it. Worldwide, the transport sector contributes $26 \%$ of global $\mathrm{CO}_{2}$ emissions and is one of the few sectors where emissions are still growing [4]. 
Another problem is air pollution. The latter primarily results from a steep increase in vehicle use. Every year, the number of vehicles in Bandung City (the third largest city in Indonesia) has increased $10-15 \%$. Meanwhile the increase in road construction has been at $0.45 \%$ per year [5]. This has inevitably led to congestion in Bandung City [6,7]. This problem is exacerbated by a lack of green open spaces $( \pm 7.86 \%$ of the total Bandung City area-far less than the legally binding target of $30 \%$ ) [8]. The transport sector is also responsible for rising health care costs and for a loss of general welfare [9]. Furthermore, economic loss attributable to traffic congestion [10] has reached 4.63 trillion rupiah per annum (equivalent to $\$$ US 0.4 billion) [11].

Other related problems are a lack of clarity in measuring GHG emissions (a potential reduction in each action) and a lack of information about co-benefits [12]. The co-benefits are defined as benefits to the local environment because of mitigation actions/adaptation in addressing global environmental change [13]. A lack of awareness and differences in the priority given to sectors are other barriers to promoting co-benefits [14].

Several concepts of global climate change and local air pollution control have received increased attention in academic literature, e.g., sustainable urban transportation $[15,16]$. Another approach, which deals simultaneously with both the global and the local problems, is the so-called co-benefits approach [17-23]. The concept of "Sustainable Cities" [24] also addresses how cities can govern better to cope with climate change and focus on enabling actual spatial transformation, rather than only institutional change [24,25]. In practice, low-carbon cities have been used as a concept to mitigate climate change in developed countries, particularly in household energy management $[24,26]$. The co-benefit approach is a suitable focus for action [18,27]. It could support an integrated program to develop and implement policies that simultaneously both contribute to lowering GHG emissions, while, at the same time, address local socioeconomic sustainability challenges.

In this paper, the main research question is how the role of governance becomes effective to incorporate air pollution control. The policy also benefits the reduction of GHG emissions mitigation in the transport sector of Bandung. It signals that local governments apparently give little attention to mitigating climate change, but do mitigate air pollution. The paper examines to what extent air pollution policies can contribute to climate change mitigation in Bandung City.

The paper is divided into five sections. The next section (Section 2) reviews the relevant literature on air pollution control that address climate change (mitigation) or low carbon governance by cities and on co-benefits. The theoretical aspects of the CIT (Contextual Interaction Theory) framework are presented in the third section. The CIT framework is used to analyse climate governance in the Bandung City transport sector case and analysed further on the structural context for governance analysis. The research design and methods are discussed in the fourth section. The fifth section presents the results of the Bandung City case study, together with a discussion of the results. The paper ends by drawing conclusions and making recommendations for future research.

\section{Low-Carbon Transport Governance and Co-Benefits}

The 1987 Brundtland Commission report introduced the concept of sustainable development. Here stakeholders have to collaborate to implement its principles in the cities [16]. The concept of sustainable development led to new concepts, including: sustainable transport [28], sustainable urban transport [16], environmentally sustainable transport [29], sustainable low carbon transport [30], sustainable cities [31], and co-benefits [32]. The concept of sustainable transportation is multi-dimensional and encompasses three areas: (1) implementing technology; (2) pricing and financing; and (3) integrated transport and land use planning $[15,16,28]$. Further research in policy implementation is necessary to understand how this concept was developed and integrated in the program of climate change mitigation in Indonesia.

Bulkeley [24] studied modes of governing in terms of the reduction of GHG emissions. A framework was used which was adapted from the UN Habitat report. There are seven modes of low carbon governance that cities use [24]: (1) municipal self-governance; (2) municipal provision; (3) municipal regulation; (4) municipal enabling (predominantly governed by the municipality); 
(5) non-state voluntary; (6) public-private provision and (7) non-state mobilization (private-sector actors). Governance approaches by local government include forms of self-governance (e.g., staff travel planning, vehicle fleet fuel switching based on local readiness), regulations (e.g., emissions standards, planning laws), provision (e.g., of public transport service or infrastructure for alternative modes of travel), enabling (e.g., information) and partnerships (e.g., public-private financing for new modes of transportation) [31].

According to Bulkeley et al. [31], there are four key motivations for climate policy and actions that local governments have: leadership, the stimulus from the central government to local governments, resources and issue framing. In terms of leadership, Bulkeley et al. [31] found that individual political 'champions', such as the Mayor of Yogyakarta, are important actors supporting advance initiatives (e.g., a program to retrofit lights and reduce air conditioning hours and bulbs, change travel behaviour, and developed BRT).

The stimulus of central governments (China and South Korea) has been a crucial factor in developing the political space (authority) for local government action on climate change (in public transport provision and street lighting). The available resources are also very important. This is exemplified in the Seoul case study illustrating the funds allocated for climate change action to finance research, technology development and mitigation schemes, to support renewable energy and also to improve energy accessibility and promote greater energy efficient [31].

Issue framing is considered a critical factor in climate change policy and action. First, it is important for energy security and fuel efficiency to help eradicate poverty. Second, framing low-carbon strategies in term of air quality and health problems have led to some initiative by local actors in the transport sector in all the case studies described in this paper.

In the Contextual Interaction Theory (CIT), Bressers [33] addresses motivation as a key actor characteristic that drives social interaction processes that the processes, in turn, reshape. However, resources are not part of the motivation, but are included as a variable of actor characteristics.

Most cities in Indonesia face considerable barriers to address climate change; notably in coordinating policy action, obtaining resources, operating in national level frameworks, which do not always facilitate local action [34], and in the often-conflicting aims of climate protection and economic growth [31]. Categories involving policies and mechanisms, cognitions and capacities have advantages and disadvantages. Other factors mentioned by Bulkeley [24] that are barriers and drivers of climate change mitigation efforts were institutional, political and socio-technical factors. The CIT framework treats these as the wider context and structural context, which will be presented in governance analysis framework.

\section{The Concept of Co-Benefits}

Local environmental issues — such as air quality, congestion and health-are primary issues for governments to deal with. Therefore, there have been several attempts by local government to overcome the problems. Various notions have emerged in the literature to define the concept of co-benefits. On the one hand, some approaches aim to tackle local environmental problems and overcome the global climate change problems at the same time. These often involve climate change mitigation efforts from several related sectors, such as transport, city planning, and the water, energy and health sectors $[17,18,23]$. This concept was developed in the Third Assessment Report (2001) by the Intergovernmental Panel on Climate Change (IPCC). This co-benefits concept also draws on the concept of environmental externalities [14].

Co-benefit approaches refer to the development and implementation of policies and strategies that simultaneously contribute to mitigating global change, while addressing local environmental issues and the impact on other developments. The CIT framework will analyse the co-benefits and actor characteristics. For developing countries struggling to deal with local problems, trying to implement climate change mitigation policy is often a step too far, which is why few cities in developing countries actually implement such policies $[13,20,34]$. Understanding the importance of governance in helping 
urban areas cope with climate change can provide useful lessons when designing tools for analysing and evaluating urban climate change programs.

\section{Contextual Interaction Theory (CIT) Framework}

This paper is intended to address how effectively the air quality policy has been implemented, using actor-based research. The research addresses the program instrument that also has the benefit of mitigating climate change. The literature suggests that implementing a policy model has developed from top-down [35-37], bottom-up [38-40] and synthesizers [41-45]. Differing views and methodological perspectives in policy research show the pivotal considerations of authority and legitimacy as to how implementation problems are learned. Rothstein [46] divided various government measures into operative conditions. According to O'Toole [47], the concept of governance emphasized understanding how well the multi-level character became an essential part of governance study. Other literature shows that the concept of governance is a broad one and is used in many ways (such as governance in a hollow state [48]; governance in the UN that more focuses in combating the shortcomings [49]; governing the commons as introduced by Ostrom [50]). Governance of climate change was introduced by Bulkeley et al. [31] in her research.

Eventually, the theory of implementation will lead to research about the actors, including research on how implementers and the target interact with each other and their motives, cognitions and resources. The Contextual Interaction Theory (CIT) from Bressers [33] can map actors' characteristics in different layers. The interaction process maps relationships between the local level in Bandung City and other actors (both vertical and horizontal) and then divides them between various contexts (the wider context, structural context and specific context). The context based on actor interaction is influential in addressing climate change mitigation (Figure 1).

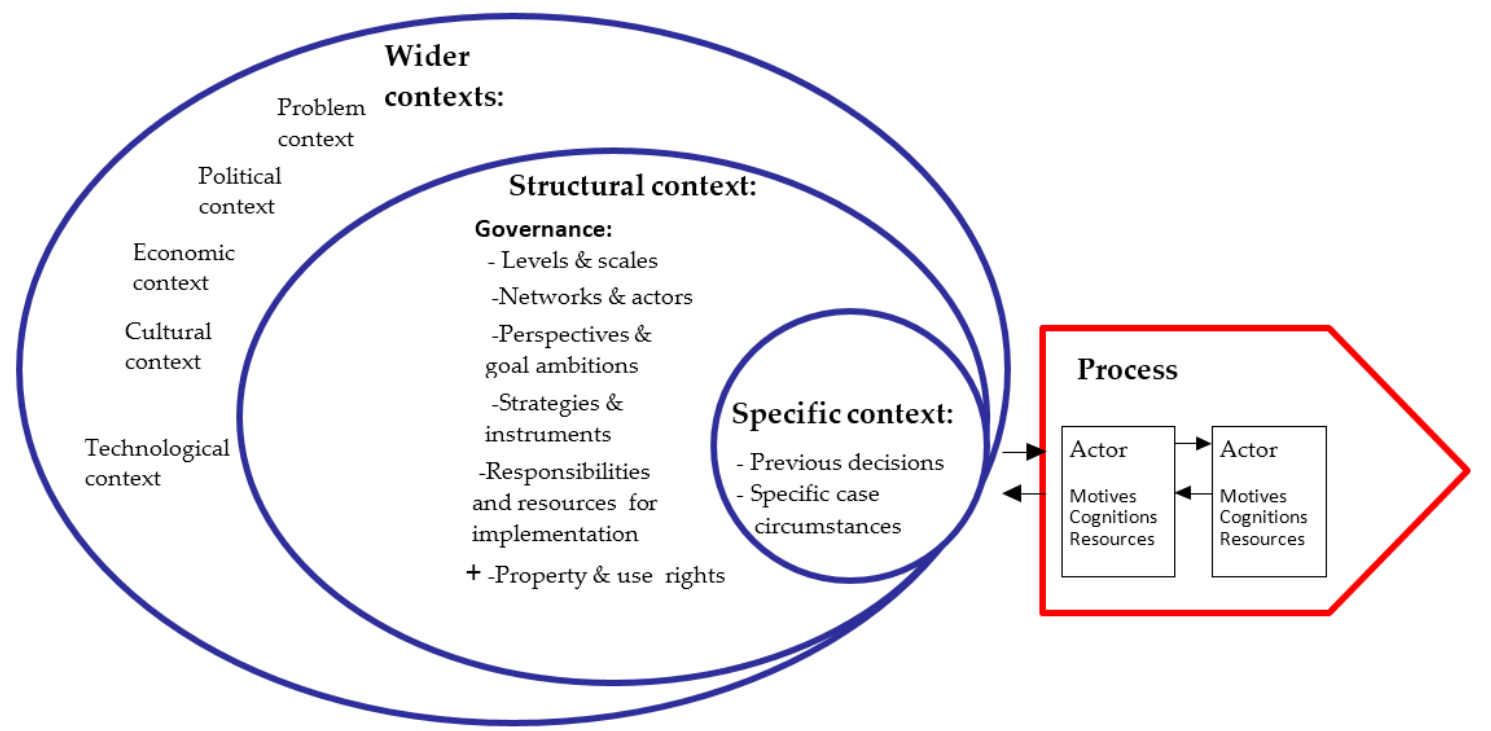

Figure 1. Contextual Interaction Theory (reproduced with permission from [33]).

Research into the central role of actors (characteristics) to explain the interaction processes is crucial to CIT. It focuses on three core characteristics: motivation-cognitions-resources as defined by Bressers [51] and as a refinement of motivation, information and power. The structural context consists of elements of governance linked with relevant property and use rights. The wider context consists of elements of problem, political, economic, and cultural and the technological content (Figure 1). CIT was developed as a theory of implementation and has been used mainly in studies analysing policy in the environmental context and sustainable development, mostly in developed countries [52]. Lately, this framework has been more widely used in developing countries [53,54]. The implementer is the 
actor who is "officially commissioned to promote the envisaged measures". The target is the "actor necessary to realize (the measures)", such as citizens or companies [54].

Figure 1 is a schematic of how the interaction process occurs between actors. Various combinations of actor characteristics help describe the process of interaction between actors. This paper will assess how the regional and local levels of lowering GHG relate to the core characteristics defined in the red box where the dynamic process of actor interaction takes place. Knowing the core characteristics of the actors allows prediction and/or explanation of interaction processes in the implementation of certain projects [55].

\section{Methods}

This study will examine the transport sector and air pollution control in Bandung City and consider how the air quality improvement policies contribute to climate change mitigation. To address the main research question, case studies broken down into two consecutive phases were used. The first phase is descriptive of actors' perspectives on local issues and programs, especially air quality programs and the contribution of these to climate change mitigation. The results are input in the second phase to help assess programs for their effectiveness when based on the actors' estimation, interaction processes of actors, and other governance factors. The selection of actors considers actor objectives and responsibilities, and their perception of the other actors. All local level actors were chosen from the same region using the theoretical framework of which actors would be best.

\subsection{Data Collection: Interview and Secondary Data}

Data were gathered from a variety of sources. Primary data targeted the provincial level (as representative of the national level) and local level in the same region and used field interviews with people from the development planning agency, transport department, environmental and forestry, land use planning, and public transport. Secondary data comprised documents (policies and programs). Documents used included a climate change mitigation action plan, a midterm plan, a strategic plan, a working plan, a performance accountability report and a technical report on the current environmental status and the transport sector. Official statistics were used as much as possible. Data sources were triangulated to check for consistency. Where inconsistencies existed, estimates provided by knowledgeable local officials were used.

\subsection{Data Analysis and Results}

Data were analysed by use of Atlas.ti software by highlighting responses in each section of interest in order to build a narrative. Data were interpreted and grouped using Contextual Interaction Theory (e.g., the concept of actor characteristics of motivation, cognitions and resources). Using the Atlas.ti software simplified data analysis, especially in coding actor interpretations and perceptions of the programs. An example of such coding can be found in Section 4.2.4, where it is used to capture the Mayor's motivations in the policy implementation process.

\subsubsection{General Introduction to the Bandung Case Study}

Bandung City is the capital of West Java (see Figure 2). It is the most densely populated province in Indonesia. Nowadays, it has become a metropolitan area called the Greater Bandung Metropolitan Area (BMA). Bandung is a core city of metropolitan areas surrounded by suburban areas that are municipalities (Bandung, West Bandung, Sumedang, Indonesia) and Cimahi City. The intensity of daily commuting in the hinterland of the four cities to core cities varies between morning and night. In 2010, Bandung's population reached 2.5 million at night and 3 million people during the day [8]. In 2012, the total trips in the Greater Bandung Metropolitan area reached 3.57 million people per day and is expected to rise by $60 \%$ by 2020 (5.57 million people/day) [56].

Transportation problems in Bandung City appear when the capacity of the transportation infrastructure is unable to meet increasing travel demand. In 2009, there were 32 primary traffic 
congestion locations in Bandung City. These were caused by economic activities (e.g., street vendors, market places, paratransit-a minibus that has small capacity) and increased use of motorized transport (see Table 1). However, in 2013 the traffic congestion scattered in 44 locations [57].

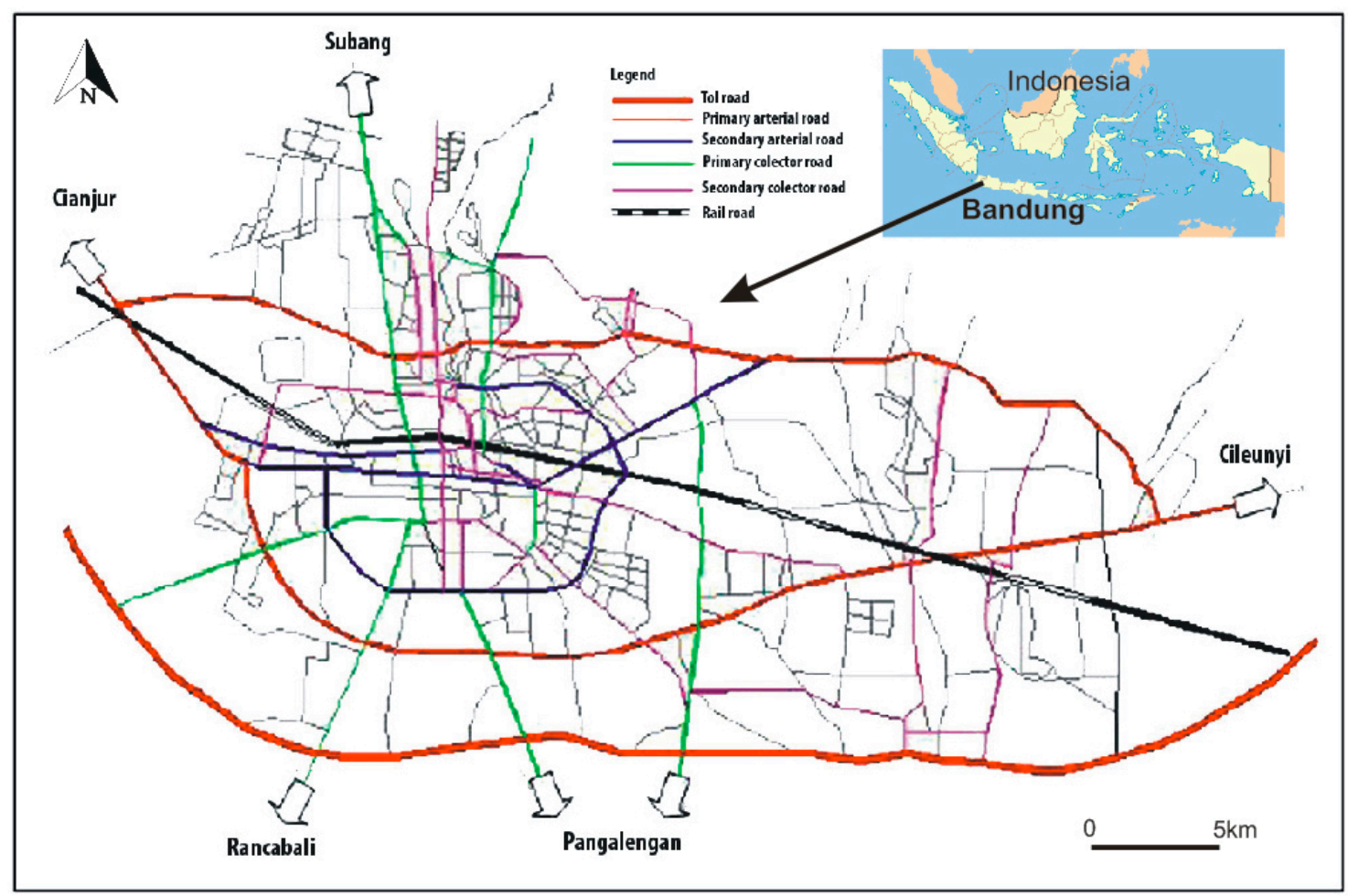

Figure 2. Greater Bandung metropolitan area 2017. Source: adapted from [56].

Table 1. The number of public and private vehicles based on type in Bandung City.

\begin{tabular}{ccc}
\hline No. & Type of Vehicles & Quantity \\
\hline 1 & Private motorcycle & $1,030,729$ \\
2 & Private car & 318,598 \\
3 & Public bus transport & 3166 \\
4 & Non-public bus & 2181 \\
5 & Taxi & 1856 \\
6 & Paratransit (angkot) & 5521 \\
& Total & $1,362,051$ \\
\hline
\end{tabular}

Source: Data from [58].

Currently, $80 \%$ of the local road network capacity in Greater Bandung has reached saturation. The main public transport in core cities still relies on the paratransit and buses with limited routes and limited quantities, such as Bus Rapid Transit (BRT). Rail-based public transports serve only a small part of the travel demand (east-west path) and does not have the capacity to meet the increasing traffic demand. There are three main impacts of transportation in Bandung City (see Table 2). 
Table 2. Impact of transportation in Bandung City.

\begin{tabular}{|c|c|c|}
\hline Economic Impact & Environmental Impact & Social Impact \\
\hline $\begin{array}{l}\text { Transportation costs in Bandung city } \\
\text { US } \$ 33.5 / \text { month or equal to } 22 \% \text { of } \\
\text { gross-expenditure (ideally no more } \\
\text { than } 20 \% \text { ) } \\
\text { Total cost of transportation in Greater } \\
\text { Bandung (2013) equal to US } \$ 1.42 \\
\text { billion / year (equal to } 10.3 \% \text { regional } \\
\text { gross domestic product) and ideally } \\
\text { no more than } 7 \%\end{array}$ & $\begin{array}{l}\text { - Contribute more than } 66 \% \text { of } \\
\text { emissions of } \mathrm{CO}_{2} \text { equivalent in } \\
\text { Bandung City (motorized fuel } \\
\text { consumption around } 627 \text { million } \\
\text { litre/year) } \\
\text { Land use change because of } \\
\text { transport infrastructure in } \\
\text { Bandung City (increase of length } \\
\text { road is } 1 \% \text {; increase of vehicle } \\
\text { number is } 9 \% \text { per year) } \\
\text { Local air pollution (vehicles } \\
\text { growth rate } 12-21 \% \text { per year) }\end{array}$ & $\begin{array}{l}\text { - Number of traffic accident increase } \\
22 \% \text { per year } \\
\text { - } \quad \text { Effect of congestion on physical } \\
\text { and mental health increase (cannot } \\
\text { be measured by local government) }\end{array}$ \\
\hline
\end{tabular}

Sources: Stakeholder analysis, Data from [8,58].

Greater Bandung Metropolitan Area (BMA) has become a priority for the regional government (West Java Provincial). The focus is to manage the areas between Bandung city and surrounding cities, as mentioned in Governor Decree no. 70 year 2013. Managing Greater BMA is important not only for its economic development, but also for its transportation network and infrastructure. There are three classes of GHG emissions in Bandung City (see Figure 3). The energy and transport sectors are responsible for most emissions, particularly in the sub-sector of road transportation.

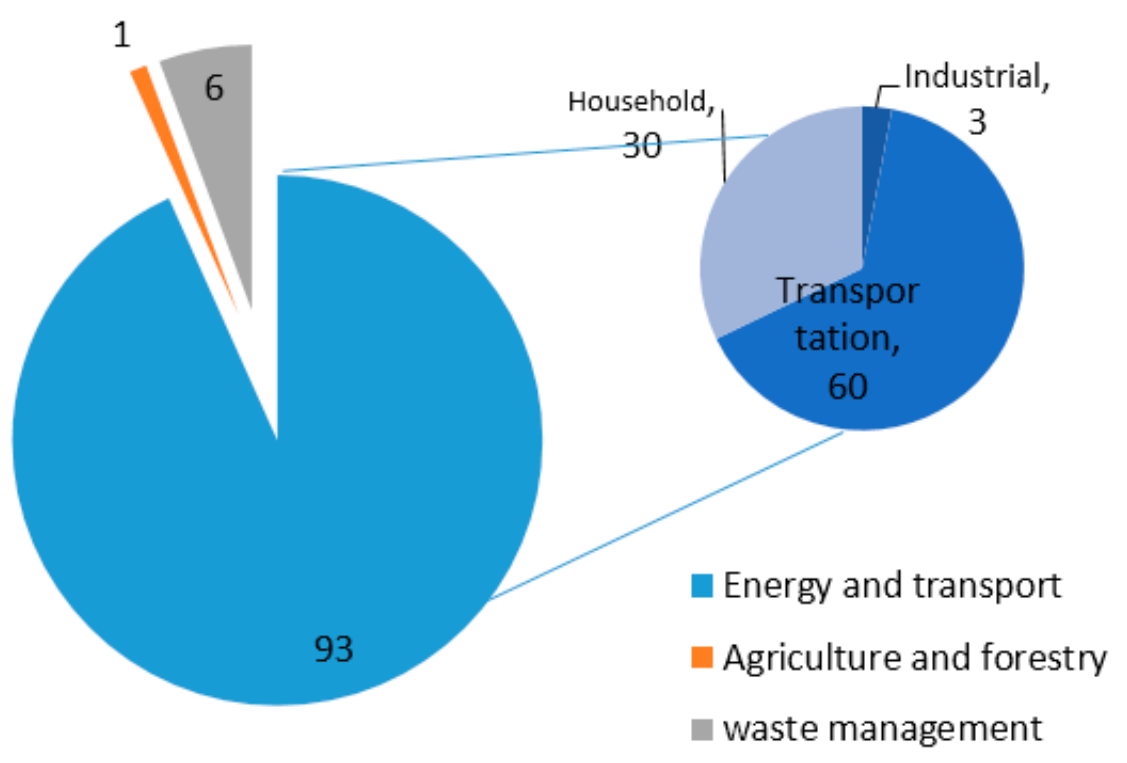

Figure 3. GHG emissions per sector in Bandung City 2013. Source: Adapted from [8].

From guidance to lower GHG emissions as published by Bandung Environmental Management Agency (EMA), the strategies in the transport sector will also contribute to the reduction of the air pollution. The strategies are: (1) to avoid or reduce the number of trips that are not strictly necessary; (2) to shift to other environmentally friendly vehicles or forms of non-motorized transportation; and (3) and to improve efficiency of vehicles by improving vehicle technologies.

4.2.2. Chronology of Mitigation Events and Assessment of Core Characteristics of Bandung City Actors

This section presents the chronology of key events in climate change mitigation policy making in Bandung City. In Indonesia, the climate change mitigation effort, based on the National Action Plan on reducing GHG (RAN-GRK), as mentioned in the Presidential Decree No. 61 Year 2011, shows 
that the forestry sector and the peatland sector are the main sectors targeted for GHG emissions reduction $\left(88.6 \%\right.$ or equivalent to 0.672 Giga ton $\left.\mathrm{CO}_{2} \mathrm{e}\right)$ followed by waste management $(6 \%)$, energy and transport (5\%), agricultural (1\%) and industry $(0.13 \%)$. Although energy and transport come in third place, urban areas are the largest contributor of GHG emissions, especially in Java [59]. This indicates increasing GHG emissions in the transport sector as a major source in Bandung City (60\% or $1394.98 \mathrm{Gg} \mathrm{CO}_{2}$ equivalent from road transport). Transport is also the sector contributing the most to air pollution, particularly from the intensive use of motor vehicles $60-88 \%$ [8]. The air quality from roadside monitoring every year shows an increase (by 4-8 times) in the concentrations of hydrocarbon, $\mathrm{PM}_{10}$ and $\mathrm{CO}$ (in particular $\mathrm{PM}_{10}$ exceeded the WHO standard) [60].

After the Conference of Parties (COP) 15 in the Copenhagen Accord and G-20 Pittsburgh assembly, the Government of Indonesia (GoI) committed to reducing GHG emissions. This commitment is driven by top-down, rather than bottom-up strategies. Implementation challenges in developing countries that lack effective central regulatory regimes and plentiful budgets need the help of bottom-up analysts [61,62].

Three years after COP 15, the GoI developed a National Appropriate Mitigation Action (NAMA), which aims to implement actions below the national level. However, reducing GHG emissions from the transport sector, not only carried on by the central government, but also by designing and implementing a focus at local levels [63]. The NAMA development process in Indonesia also predominantly followed a top-down approach. The NAMA guidelines came from National Development Planning Agency (BAPENNAS) and it is embedded in national government policies, both mid-term and long-term. Provincial level governments were not involved in drafting the National GHG reduction plan (RAN-GRK). However, they were involved at a later stage when RAN-GRK was finished. Provincial level governments developed their own GHG reduction plans [34]. Moreover, the provincial plans also became guide for local level governments to mitigate climate change in the transport sector. In West Java, the provincial government compiled guidelines for achieving the regional GHG reduction plan that stipulated on Governor Decree No. 56 Year 2012 about RAD-GRK 2012-2020. It contains the baseline of GHG emissions, general descriptions of the emitters, as well as mitigation actions and suggestions on how to measure GHG emissions.

However, the provincial level government assumed that GHG reduction activities would be conducted at the local level of Bandung City. The provincial level and local levels hold different perspectives on the implementation of policy instruments (see Table 2) to lower GHG emissions. From the interviews with the stakeholders at the local level, it appears that no particular program for mitigation exists. The ongoing programs are acknowledged, as are environment and transport programs. Nonetheless, the Transportation Department states that several programs could potentially contribute to lowering GHG emissions (e.g., by CFD, traffic management, non-motorized transport, parking management, intelligent transport systems, and by monitoring of urban air quality). These findings may be an opportunity to promote climate change as a means to address local problems, as well as to mitigate climate change $[25,64]$.

It is also known that, although supplemented by various guidelines from the national, regional and local levels, evidence of lowering GHG emissions in the transport sector is not visible. This is evident from annual local action plans in the transport department and EMA that lacked any action for mitigating climate change. This conclusion is also reinforced by the results of interviews with the local planning agency (Bappeda). This means that lowering GHG at the local level is not a top priority for local government compared to addressing local problems, such as traffic congestion, water pollution and waste reduction that appear as a more serious challenge in Bandung. This situation does depend on actor motives and their cognition in the consensus development plan. The consensus of development plan (musrenbang) is a mechanism dialogue between the parties (stakeholders) related to both direct and indirect benefits as a participatory approach to local development planning. Other reasons come from the local government perception of climate change. This is seen as simply 
a subset of a wider range of natural disasters, hazard risks, and domestic political pressures that undermine the international commitments to lowering GHG emissions in Indonesia [65].

However, an interesting approach came from the Mayor of Bandung. He has prioritized the development of thematic gardens to solving severe existing environmental problems (congestion, street vendors, waste, floods and transportation) ever since he was first elected. The aim of the Mayor's policy is to increase the citizens' level of happiness first, and then fix climate change problems later in a gradual manner. Beside the thematic garden, the Mayor also developed thematic days, which have become routine activities for Bandung citizens. Those contributing to climate change mitigation include: (1) bus rides to schools every Monday; (2) cycling on Fridays and (3) a Car-Free Day (CFD) on Sundays. The Institute for Global Environmental Strategies (IGES) initiated the workshop for stakeholders in Bandung in 2015 regarding the co-benefits of transport sectors. This workshop aimed to realise sustainable urban transport in Bandung City [66].

This form of leadership is one of four drivers for climate change policy and action by local government (as also mentioned by Bulkeley et al. [31]). Leadership attract other organizations to participate in climate policy. It shows that individual political 'champions' have an important role to play in supporting progressive initiatives. This also could help obtaining access to external funding that has been implemented in Bandung City in several programs (bike rental spots and Bandros (tourist bus)) which comes from Corporate Social Responsibility (CSR) funding.

The actors have estimated the contribution of the existing program to climate change mitigation. Some local government still needed to acknowledge the programs that contribute to GHG emissions reduction from its activities. Even though, EMA already found difficulties in gathering emissions data from all sectors. In line with the national target, local levels have to decrease their emissions by $2 \%$ per year. However, measuring emissions levels to obtain primary data proves to be very difficult. Until now, the process of auction for collecting the emissions data is failing because no one is capable to carry it out (do not meet the technical requirement).

Actors' understanding about the mitigation context also came from their knowledge of other actors involved in reducing GHG emissions. The Environmental Management Agency, which is in charge of the air quality improvement program at the provincial and local levels, already knew that the transportation department has the most important role and authority to mitigate climate change and lower GHG emissions.

There are nine programs or policies that relate to the lowering of GHG emissions in the transport sector at the local and provincial levels (see also Table 3). The strategy is based on the so-called 'avoid-shift-improve' paradigm. This is a framework for climate change mitigation of sustainable urban mobility that is generally used by GIZ and IGES [12].

However, GHG emissions monitoring does not support the existing policies. This practice is not in line with UNFCCC guidelines, which state that: "the effects of climate change mitigation actions should be documented in accordance with best methodologies and practices (fixed by multinational bodies, such as UNFCCC), and must be tractable and comparable in transparent ways" [67]. Firstly, in Bandung City, the existing measure aims at ensuring that emissions inventories are updated periodically (based on Presidential Decree No. 71 year 2011). Secondly, the measurement activity is to report the achievement in reducing GHG emissions based on potential GHG emissions from various sectors.

Therefore, the relevant municipal competencies and availabilities for taking emissions measurements in Bandung City need more attention. The authorities for collecting data in the transport sector are not clearly defined. The Local Transportation Department assumed that it was not their duty to measure GHG emissions and therefore face difficulties in measuring the emissions from their program (public transport). However, other local governments (EMA) conducted the emissions inventory, not necessarily for GHG emissions. 
Table 3. Particular policies that could contribute to lowering GHG emissions.

\begin{tabular}{|c|c|c|c|c|c|c|c|}
\hline No & Policies & Budget or Finance & Original Purpose and Co-Benefits & Implementer \& Legal Basis & Target Group & Strategy & $\begin{array}{c}\text { Level of } \\
\text { Important * }\end{array}$ \\
\hline 1 & $\begin{array}{l}\text { Paratransit (minibus } \\
\text { with 12-14 passengers) }\end{array}$ & $\begin{array}{l}\text { Paratransit owners } \\
\text { Local level (vehicle test) }\end{array}$ & $\begin{array}{l}\text { Meet the human need for movement } \\
\text { Co-benefits: } \\
\text { 1. Increasing fuel economic } \\
\text { 2. Reduce spending money } \\
\text { 3. } \quad \text { Unravel congestion }\end{array}$ & $\begin{array}{l}\text { Bandung Transportation Department } \\
\text { Legal basis: } \\
\text { SK Director General of Land No. } 6872002 \text { Technical } \\
\text { Guidelines on the Implementation Public Transport in } \\
\text { the Region Urban in Fixed Route and Organized }\end{array}$ & $\begin{array}{l}\text { Passenger } \\
\text { Car \& motorcycle } \\
\text { owner }\end{array}$ & Shift & +++ \\
\hline 2 & $\begin{array}{l}\text { Car-free day (CFD) and } \\
\text { Car-free night (CFN) }\end{array}$ & $\begin{array}{l}\text { Local level (tourism and health } \\
\text { activities; janitor, security) } \\
\text { Central government, provincial } \\
\text { government and local level } \\
\text { (cultural heritage-Jl. Asia Africa) }\end{array}$ & $\begin{array}{l}\text { Better air quality } \\
\text { Co-benefits } \\
\text { 1. Improved health } \\
\text { 2. Enhancing local economic } \\
3 . \quad \text { Tourism attraction } \\
4 . \quad \text { Dissemination of information }\end{array}$ & $\begin{array}{l}\text { Bandung Transportation Department; Bandung } \\
\text { Tourism Agency; Bandung City Police } \\
\text { Legal basis: } \\
\text { - Mayor decree No. } 551 / \text { Kep.449-Affair of } 2011 \text { on } \\
\text { the implementation of Car-Free Days in Bandung } \\
\text { - Mayor Regulation No. } 888 \text { of } 2010 \text { on } \\
\quad \text { Management and Development Street Vendors }\end{array}$ & $\begin{array}{l}\text { Car users } \\
\text { Authorities } \\
\text { Families } \\
\text { Students } \\
\text { Street vendors } \\
\text { Property owners }\end{array}$ & $\begin{array}{c}\text { Avoid (Land } \\
\text { use-behavioural } \\
\text { change) or Push policy }\end{array}$ & +++ \\
\hline 3 & $\begin{array}{l}\text { Vehicle test feasibility } \\
\text { and emissions test (part } \\
\text { of EKUP) }\end{array}$ & $\begin{array}{l}\text { Local level (vehicle test with } \\
\text { transport department and } \\
\text { emissions test with environmental } \\
\text { management) }\end{array}$ & $\begin{array}{l}\text { Safety driving and better air quality } \\
\text { Co-benefits } \\
\text { 1. Increasing fuel economic of vehicle } \\
2 . \quad \text { Reducing future operating costs }\end{array}$ & $\begin{array}{l}\text { Bandung Transportation Department; Bandung } \\
\text { Environmental Management Agency } \\
\text { Legal basis: } \\
\text { - Minister of Environment Regulation No. } 5 \text { of } 2006 \\
\text { on the threshold of motor vehicle } \\
\text { exhaust emissions } \\
\text { Bandung Regional Regulation No. } 11 \text { of } 2005 \text { on } \\
\text { the implementation of discipline, cleanliness, } \\
\text { and beauty }\end{array}$ & Car users & Improve & +++ \\
\hline 4 & $\begin{array}{l}\text { Trans Metro Bandung } \\
\text { (TMB) and School bus }\end{array}$ & $\begin{array}{l}\text { Local level (shelters and buses) } \\
\text { Central government (Buses } \\
\text { provision for TMB) }\end{array}$ & $\begin{array}{l}\text { Improve occupancy rates and Improve using } \\
\text { of public transportation } \\
\text { Co-benefits: } \\
\text { 1. Reduce spending money } \\
\text { 2. Unravel congestion } \\
\text { 3. Increasing fuel economic }\end{array}$ & $\begin{array}{l}\text { Bandung Transportation Department } \\
\text { Legal basis: } \\
\text { - Bandung Mayor Decision No. } \\
\text { 551/Kep.764-Transportation/2012 on Operation } \\
\text { Trans Metro Bandung In Corridor } 2 \\
\text { Cicaheum-Cibereum in Bandung } \\
\text { Bandung Mayor's decision number } \\
\text { 551.2/694-Transportation Kep/2008 on the tariff } \\
\text { mass transit bus Trans Metro Bandung } \\
\text { Bandung Mayor Regulation No. 704 of } 2008 \text { on } \\
\text { Minimum Service Standards (MSS) operation } \\
\text { of TMB }\end{array}$ & $\begin{array}{l}\text { Passenger } \\
\text { Authorities } \\
\text { Car \& motorcycle } \\
\text { owner }\end{array}$ & Shift (usage larger unit) & +++ \\
\hline 5 & $\begin{array}{l}\text { Cycling policy as part of } \\
\text { "Thematic day"; } \\
\text { Pedestrian walk lane } \\
\text { and Bike Park } \\
\text { (infrastructure) }\end{array}$ & $\begin{array}{l}\text { Local level (bike lanes; pedestrian } \\
\text { walk lane, bike shelters) }\end{array}$ & $\begin{array}{l}\text { 1. Better air quality } \\
\text { 2. Health improvement } \\
\text { Co benefits: } \\
\text { 1. Lowering cost } \\
\text { 2. Unravel traffic congestion }\end{array}$ & $\begin{array}{l}\text { Bandung Environmental Management Agency; } \\
\text { Bandung Spatial and Public works agency; Department } \\
\text { Youth and Sport } \\
\text { Legal Basis: } \\
\text { - Bandung Regional Regulation No. } 16 / 2012 \text { on the } \\
\text { Implementation of Transportation and Retribution } \\
\text { in the Field Transportation (article } 12 \text { and 32) }\end{array}$ & $\begin{array}{l}\text { Car users } \\
\text { Employee }\end{array}$ & $\begin{array}{l}\text { Shift } \\
\text { (Pull policy) as } \\
\text { Non-motorized } \\
\text { transport (NMT) }\end{array}$ & ++ \\
\hline
\end{tabular}


Table 3. Cont

\begin{tabular}{|c|c|c|c|c|c|c|c|}
\hline No & Policies & Budget or Finance & Original Purpose and Co-Benefits & Implementer \& Legal Basis & Target Group & Strategy & $\begin{array}{c}\text { Level of } \\
\text { Important * }\end{array}$ \\
\hline 6 & $\begin{array}{l}\text { Four in one } \\
\text { (every Saturday) }\end{array}$ & Local level (traffic sign) & $\begin{array}{l}\text { Reduce traffic loading in particular area } \\
\text { (four passengers for one car) } \\
\text { Co benefits: } \\
\text { 1. Reduce VCR in specific road } \\
2 . \quad \text { Unravel congestion }\end{array}$ & $\begin{array}{l}\text { Bandung Transportation Department; Bandung City } \\
\text { Police } \\
\text { Legal basis: } \\
\text { - Mayor decree No.551/Kep.582-Dishub/2013 } \\
\text { regarding Stipulation of Zone Traffic Control and } \\
\text { Liability Transporting at least } 4 \text { People Passenger } \\
\text { Vehicle For Individuals At the Roads Specific } \\
\text { in Bandung }\end{array}$ & - $\quad$ Car users & $\begin{array}{l}\text { Avoid (push } \\
\text { policy) }\end{array}$ & ++ \\
\hline 7 & $\begin{array}{l}\text { Management and traffic } \\
\text { engineering (including } \\
\text { parking control) }\end{array}$ & $\begin{array}{l}\text { Local level (traffic sign and } \\
\text { operator) }\end{array}$ & $\begin{array}{l}\text { Reduce congestion and changes traffic light } \\
\text { (led light) also intensification activities in the } \\
\text { framework of Parking Control } \\
\text { Co-benefits: } \\
\text { 1. Reduce cost and maintenance }\end{array}$ & $\begin{array}{l}\text { Bandung Transportation Department Legal basis: } \\
\text { Bandung Regional Regulation No. } 11 \text { of } 2005 \text { on } \\
\text { the implementation of discipline, cleanliness, } \\
\text { and beauty } \\
\text { Mayor's decision No. } 551 / \text { Kep. } \\
\text { 737-Transportation/2012 }\end{array}$ & $\begin{array}{ll}- & \text { Car users } \\
\text { - } & \text { motorcycle } \\
& \text { users }\end{array}$ & Avoid & + \\
\hline 8 & Progressive tax on pollution & $\begin{array}{l}\text { Provincial Level (Local } \\
\text { Revenue Department of } \\
\text { West Java) }\end{array}$ & $\begin{array}{l}\text { Reduce vehicle ownership } \\
\text { Co-benefits: } \\
\text { 1. Increasing the income }\end{array}$ & $\begin{array}{l}\text { Local Revenue Department of West Java } \\
\text { Legal basis: } \\
\text { - West Java Provincial Regulation } 13 \text { in } 2011 \text { on } \\
\text { Local Taxes } \\
\text { West Java Governor Regulation No. } 33 / 2013 \text { on } \\
\text { Guidelines for the Implementation of the } \\
\text { West Java Provincial Regulation No.13 of } 2011\end{array}$ & Cars owner & $\begin{array}{l}\text { Pricing or Push } \\
\text { policy }\end{array}$ & + \\
\hline 9 & $\begin{array}{l}\text { Proklim } \\
\text { (climate village program) }\end{array}$ & $\begin{array}{l}\text { Provincial level (central level } \\
\text { from de-concentration) }\end{array}$ & $\begin{array}{l}\text { Promote adaptation and mitigation action and } \\
\text { give appreciation from central government to } \\
\text { local level } \\
\text { Other co-benefits: } \\
\text { 1. Intensified action in local level } \\
2 . \quad \text { Documentation of mitigation and } \\
\text { adaptation action }\end{array}$ & $\begin{array}{l}\text { West Java EMA } \\
\text { Legal Basis: } \\
\text { Ministry Environment Decree No. 19/2012 regarding } \\
\text { Climate Village Program (Program Kampung Iklim) }\end{array}$ & $\begin{array}{l}\text { Village } \\
\text { communities }\end{array}$ & Pull policy & + \\
\hline
\end{tabular}

*: Plus sign informs the intensity of importance of the policies (based on actors perspectives and analysis); Sources: Data collecting and interview analysis. 


\subsubsection{Overview of Key Stakeholders}

The empirical study shows that the involvement of actors related with climate change mitigation in Bandung City depends on their interest in the issue and their power basis. Only a few actors in the transport sector have higher interest (Ministry of Transportation, Local Transport Department and Local EMA). Collaboration only existed in national and provincial levels, as mentioned in the aims of RAN-GRK. Even at the local level, some implemented their initial target of GHG reduction. Local governments can decide themselves to determine the activities according to their specific abilities and particular conditions. Table 4 presents an overview of the key stakeholders.

Table 4. Stakeholders of climate change mitigation and air quality improvement in the transportation sector (Bandung City).

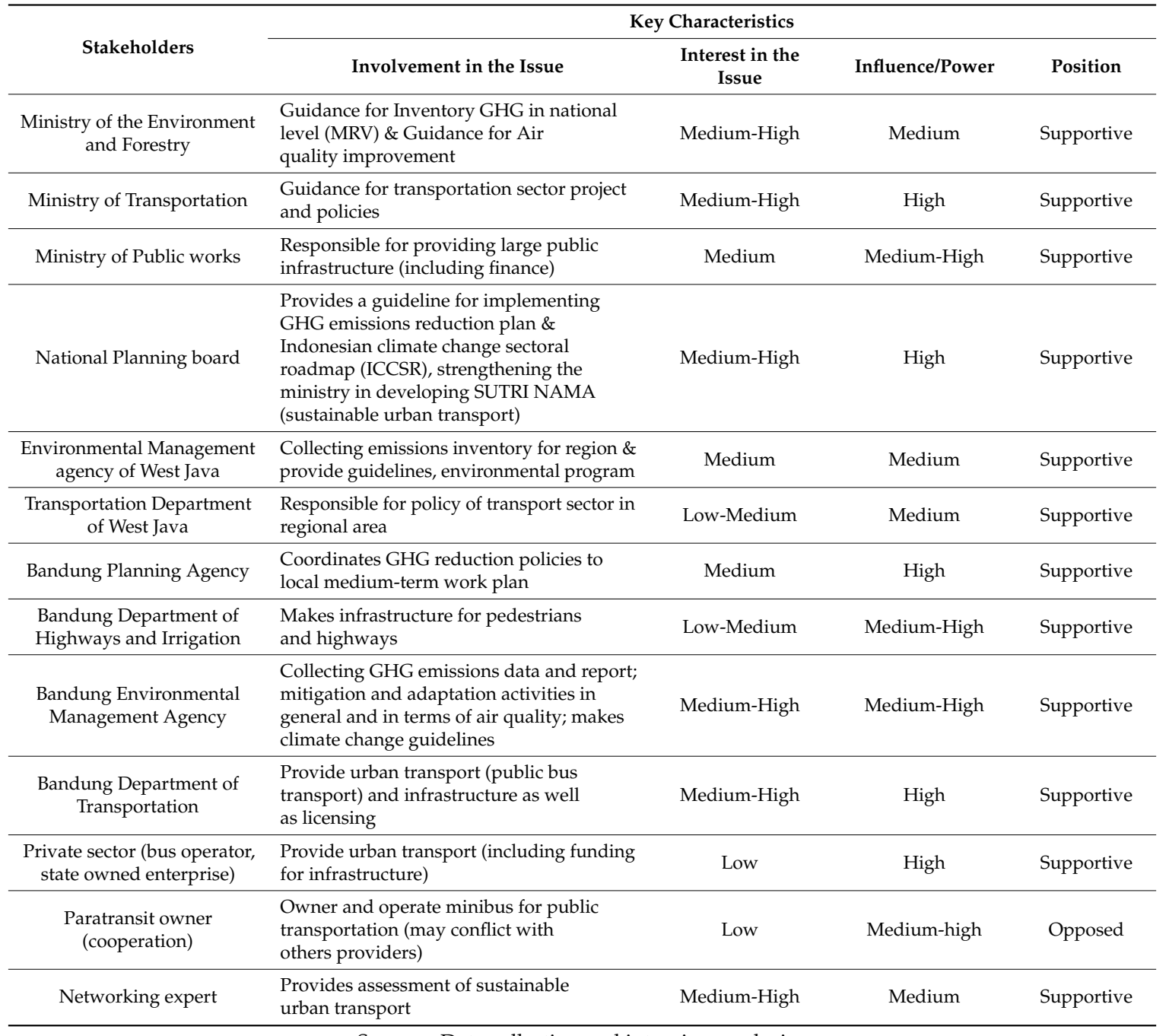

Sources: Data collecting and interview analysis.

\subsubsection{Results of the Actor Interactions Analysis}

The climate change mitigation already conducted at the local level is more focused on solid waste management and tree planting (greening). The local environmental management agency (EMA) acknowledges that their institution has to collect GHG emissions data in Bandung City, as required by central government. All stakeholders assumed that the greatest responsibility for mitigation lies with the local transport department. The dynamic actor interaction of local government actors can be seen in Figure 4. 


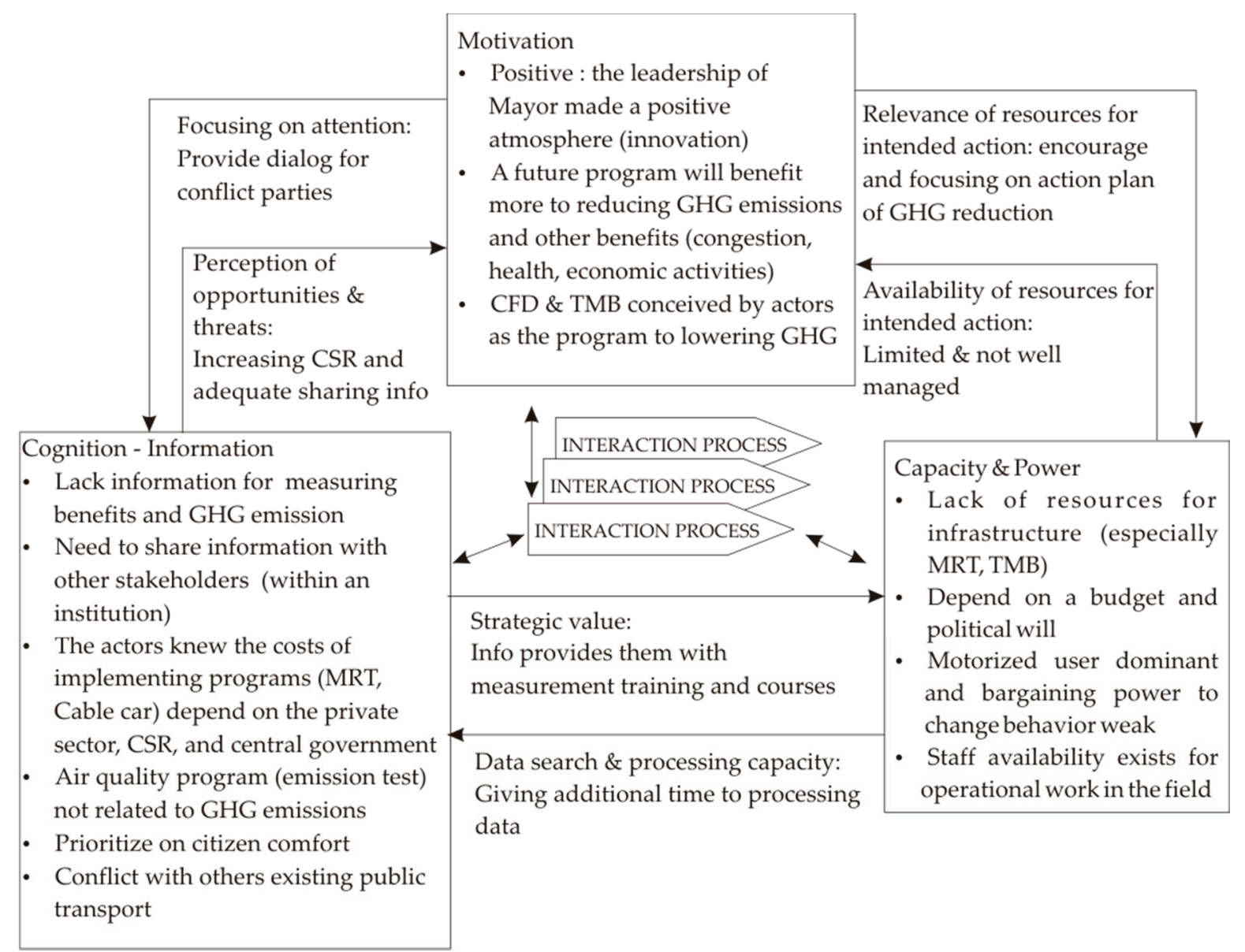

Figure 4. The dynamic actor-characteristics interaction of local-level actors (implementers). (The scheme is used with permission from [33].) Zooming in on the 'Process' in Figure 1.

The local transport department encourages the Car-Free Day (CFD) and Trans Metro Bandung (TMB) to lower GHG emissions. However, they lack adequate information and knowledge as to how these policies and the resulting reductions could be measured. They prioritize citizen comfort and reducing conflict between public transport modes (improvement public transport) rather than action to achieve climate change mitigation goals. The local transport department is aware that implementing other programs (such as those already in planning, like MRT and cable cars) requires resources that could not be afforded at the local level. However, all actors at the local level agreed that the leadership of Bandung Mayor created a positive atmosphere in providing public services in Bandung City.

It is also evident that the local level actors believe that the Mayor has the capability to influence other stakeholders, not only in Indonesia, but also from other countries interested in investing in Bandung City. There have been several flagship programs launched by the Mayor; some relate to reducing GHG emissions. The school bus programs, bicycle policies, and public transport use are programs to deal with climate change mitigation. However, challenges, such as a lack of resources for infrastructure, depend on available budgets (especially from the central government). These issues have made it difficult to implement this policy. This has led to problems, such as the dominance of motorized users in Bandung City and a lack of coordination with other regions and provinces.

Using the Contextual Interaction Theory to analyse motivations, cognitions and capacity and power as characteristics of local-level actors (see Figure 4) reveals how and why a policy is implemented in a certain manner. When analysed, the actor characteristics provide a way to understand where the actors are focusing, the opportunities available to them as well as identifying the threats that may influence the result of the implementation process. In this case, as has been discussed 
above, incorporating air pollution control with climate policy at the local level has been met with challenges that include focusing attention to managing conflict between the different actors rather than successfully promoting climate change mitigation. With regards to opportunities, the actors realise that funding through different avenues, especially CSR, could lead to successful policy implementation, but a lack of information (and knowledge), especially to measure the benefits of climate change mitigation, places them at a disadvantage.

\section{Discussion}

Despite the lack of actors who understand about air quality improvement in the transport sector and their mutual co-benefits in lowering GHG emissions, a possibility to synergize the local programs emerges from the local perspectives (municipality and provincial level). The paratransit, car-free day, vehicle emissions testing (validity test), and Trans Metro Bandung (Bus Rapid Transit) have received more attention from the public and the government. However, the role of external actors (the central government) in encouraging and supporting the local level to create positive conditions is required to create a synergy with the national goals.

Central government has a strong desire to reduce GHG emissions. However, the interest and the influence (power) to act separately among the actors, together with the lack of coordination and diverse perception of the issues, can complicate the achievement of national targets. These barriers are similar at the provincial and local levels.

Narrowing down to the local level, the positive motivations triggered by the leader of Bandung City, involving several flagship programs that promote sustainability, have been well received by the community. However, in terms of air quality improvement and climate policy, the stakeholders shared the same concerns over a lack of information and guidance on how to synergize the programs. The lack of information led to a conflict with the existing public transport. Political and financial support from the national government is the most crucial aspect to incorporating air pollution control with climate policy at the local level. This constraint will not have much influence if the cognition and motivational aspects are still weak.

\section{Conclusions}

This study has provided a preliminary assessment as to how existing programs could potentially address co-benefits. Besides air quality improvement, other benefits perceived by actors relate to health improvement, enhancing local economic, tourism attraction, and reducing congestion. Local actors' motivation to deploy climate policies is based on their local priorities. Local actors are aware of their lack of resources to develop the infrastructure for public transport and for local government to adapt their programs in low-cost budgets. When addressing local problems, it will be necessary to ascertain and cross-check the policies in the wider context.

By using the transport sector in Bandung City as one of the examples in this paper, we have also highlighted the difficulties faced by actors at different levels of government in implementing climate change mitigation policies, as expected by international policy makers.

Acknowledgment of the local perspectives of air quality improvement and climate policy can provide Bandung with a diversity of policy options. The identification of the effectiveness of the programs by certain sectors also needs analysis by other implementers and target actors.

Author Contributions: Helmi Gunawan performed analysis on all samples, interpreted data, wrote manuscript and acted as corresponding author. Hans Bressers has supervised the development of this research as the promoter of the PhD thesis on which this paper is partly based. He has also developed the key concepts of the Contextual Interaction Theory which is a framework used in this manuscript. Nthabiseng Mohlakoana helped in data interpretation and manuscript editing and assessment. Thomas Hoppe has provided input in data collection and analysis supervision.

Conflicts of Interest: The authors declare no conflict of interest. 


\section{References}

1. IPCC. Climate Change 2001: Synthesis Report; Cambridge University Press: Cambridge, UK; New York, NY, USA, 2001.

2. Ministry of Education (MoE). Indonesia Country Report: Climate Variability and Climate Change and Their Implication; Ministry of Environmental Republik of Indonesia: Jakarta, Indonesia, 2007.

3. United Nations Framework Convention on Climate Change (UNFCCC). Climate Change: Impacts, Vulnerabilities and Adaptation in Developing Countries; United National Framework Convention on Climate Change: Bonn, Germany, 2007.

4. Chapman, L. Transport and climate change: A review. J. Transp. Geogr. 2007, 15, 354-367. [CrossRef]

5. BPS Kota Bandung. The Municipality of Bandung in Figures 2015; BPS Kota Bandung: Bandung, Indonesia, 2015.

6. Bigazzi, A.Y. Traffic Congestion Mitigation as an Emissions Reduction Strategy; Portland State University: Portland, OR, USA, 2011.

7. Eldewisa, Z.D. Perbandingan Estimasi Beban Emisi CO Dan $\mathrm{CO}_{2}$ Dengan Pendekatan Konsumsi Bahan Bakar Dan Kecepatan Kendaraan (Studi Kasus: Bunderan Cibiru-Lembang) the Comparison of Co and $\mathrm{CO}_{2}$ Emission Load Estimation with Fuel Consumption and Vehicles Speed Approach. Transp. (Amst.) 2011.

8. Badan Pengelola Lingkungan Hidup Kota Bandung (BPLH). Status Lingkungan Hidup Daerah Kota Bandung; Badan Pengelola Lingkungan Hidup Kota Bandung: Bandung, Indonesia, 2013.

9. Monzon, A.; Guerrero, M.-J. Valuation of social and health effects of transport-related air pollution in Madrid (Spain). Sci. Total Environ. 2004, 334-335, 427-434. [CrossRef] [PubMed]

10. Guo, X.R.; Cheng, S.Y.; Chen, D.S.; Zhou, Y.; Wang, H.Y. Estimation of economic costs of particulate air pollution from road transport in China. Atmos. Environ. 2010, 44, 3369-3377. [CrossRef]

11. Bappeda. Review Masterplan dan Penyusunan Rancangan Peraturan Walikota Transportasi Kota Bandung; Badan Perencanaan Pembangunan Daerah Kota Bandung: Bandung, Indonesia, 2011.

12. Institute for Global Environmental Strategies (IGES). Mainstreaming Transport Co-benefits Approach. A Guide to Evaluating Transport Projects; Institute for Global Environmental Strategies (IGES): Kanagawa, Japan, 2011.

13. Puppim De Oliveira, J.A. Learning how to align climate, environmental and development objectives in cities: Lessons from the implementation of climate co-benefits initiatives in urban Asia. J. Clean. Prod. 2013, 58, 7-14. [CrossRef]

14. Yedla, S.; Park, H.-S. Co-benefit as an approach to align climate change concerns with national development objectives: Solid waste management. J. Mater. Cycles Waste Manag. 2009, 11, 123-129. [CrossRef]

15. Greene, M.; Wagener, D.L. Sustainable Transport. J. Transp. Geogr. 1997, 5, 177-190. [CrossRef]

16. Goldman, T.; Gorham, R. Sustainable urban transport: Four innovative directions. Technol. Soc. 2006, 28, 261-273. [CrossRef]

17. Lee, T.; Van De Meene, S. Comparative studies of urban climate co-benefits in Asian cities: An analysis of relationships between $\mathrm{CO}_{2}$ emissions and environmental indicators. J. Clean. Prod. 2013, 58, 15-24. [CrossRef]

18. Puppim De Oliveira, J.A.; Doll, C.N.H.; Kurniawan, T.A.; Geng, Y.; Kapshe, M.; Huisingh, D. Promoting win-win situations in climate change mitigation, local environmental quality and development in Asian cities through co-benefits. Clean. Prod. 2013, 58, 1-6. [CrossRef]

19. Creutzig, F.; Mühlhoff, R.; Römer, J. Decarbonizing urban transport in European cities: Four cases show possibly high co-benefits. Environ. Res. Lett. 2012, 7, 44042. [CrossRef]

20. Thambiran, T.; Diab, R.D. Air pollution and climate change co-benefit opportunities in the road transportation sector in Durban, South Africa. Atmos. Environ. 2011, 45, 2683-2689. [CrossRef]

21. Schwanitz, V.J.; Longden, T.; Knopf, B.; Capros, P. The implications of initiating immediate climate change mitigation-A potential for co-benefits? Technol. Forecast. Soc. Chang. 2015, 90, 166-177. [CrossRef]

22. Nemet, G.F.; Holloway, T.; Meier, P. Implications of incorporating air-quality co-benefits into climate change policymaking. Environ. Res. Lett. 2010, 5, 14007. [CrossRef]

23. Jack, D.W.; Kinney, P.L. Health co-benefits of climate mitigation in urban areas. J. Environ. Sustain. 2010, 2, 172-177. [CrossRef]

24. Bulkeley, H.; Betsill, M.M. Revisiting the urban politics of climate change. Environ. Politics 2013, 22, $136-154$. [CrossRef] 
25. Bulkeley, H. Where the Global Meets the Local? Sustainable Cities and Global Environmental Governance; Durham University: Durham, UK, 2003; pp. 16-18.

26. Angelidou, M. Smart city policies: A spatial approach. Cities 2014, 41, S3-S11. [CrossRef]

27. Dirgahayuni, P. Policy Elements to Upscale the Contribution of Urban Transit Initiatives on Sustainable Urban Transport: The Case of Bus Improvement Initiatives in Indonesia; UNU/IAS Working Paper; United Nations University: Tokyo, Japan, 2012.

28. Schiller, P.L.; Brunn, E.C.; Kenworthy, J.R. An Introduction to Sustainable Transportation Policy, Planning and Implementation; Earthscan Ltd.: London, UK, 2010.

29. Organisation for Economic Co-operation and Development (OECD). Towards Sustainable Transportation. In The Vancouver Conference; Organisation for Economic Co-Operation and Development (OECD): Paris, France, 1997; pp. 1-183.

30. Van Tilburg, X.; Wurtenberger, L.; de Coninck, H.; Bakker, S. Paving the Way for Low-Carbon Development Strategies; Energy research Centre of the Netherlands (ECN): Petten, The Netherlands, 2011.

31. Bulkeley, H.; Schroeder, H.; Janda, K.; Zhao, J.; Armstrong, A.; Chu, S.Y.; Ghosh, S. Cities and Climate Change: The role of institutions, governance and urban planning. In Cities and Climate Change: Responding to an Urgent Agenda; World Bank: Hemdon, VA, USA, 2009; pp. 125-159.

32. Bollen, J.; Guay, B.; Corfee-Morlot, J. Co-Benefits of Climate Change Mitigation Policies: Literature Review and New Results; Organisation for Economic Co-operation and Development (OECD): Paris, France, 2009.

33. Bressers, H. From Public Administration to Policy Networks: Contextual Interaction Analysis. In Rediscovering Public Law and Public Administration in Comparative Policy Analysis: A Tribute to Peter Knoepfel; Narath, S., Varone, F., Eds.; Haupt Verlag Ag: Bern, Switzerland, 2009; pp. 123-141.

34. Jaeger, A.; Nugraha, S.B.; Zusman, E.; Nakano, R.; Daggy, R. Governing sustainable low-carbon transport in Indonesia: An assessment of provincial transport plans. Nat. Resour. Forum 2015, 39, 27-40. [CrossRef]

35. Shrestha, R.M.; Pradhan, S. Co-benefits of $\mathrm{CO}_{2}$ emission reduction in a developing country. Energy Policy 2010, 38, 2586-2597. [CrossRef]

36. Jeffrey, L.P.; Wildavsky, A.B. Implementation: How Great Expectations in Washington are Dashed in Oaklandor; or, Why It's Amazing that Federal Programs Work at All, This Being a Saga of the Economic Development Administration as Told by Two Sympathetic Observers Who Seek to Build Morals; University of California Press: Oakland, CA, USA, 1973.

37. Van Meter, D.S.; van Horn, C.E. The Policy Implementation Process: A Conceptual Framework. Adm. Soc. 1975, 6, 445-488. [CrossRef]

38. Sabatier, P.A.; Mazmanian, D.A. The Implementation of Public Policy: A Framework of Analysis. Policy Stud. J. 1980, 8, 538-560. [CrossRef]

39. Lipsky, M. Street-Level Democracy: Dilemmas of the Individual in Public Services, 2010th ed.; Russel Sage Foundation: New York, NY, USA, 1980.

40. Elmore, R.F. Backward mapping: Implementation research and policy decisions. Political Sci. Q. 1980, 94, 601-616. [CrossRef]

41. Hjern, B.; Porter, D.O. Implementation Structures. A New Unit of Administrative Analysis. Organ. Stud. 1981, 2, 11-227. [CrossRef]

42. Scharpf, F. Interorganizational Policy Studies: Issues, Concepts and Perspectives; Sage Publications: London, UK, 1978.

43. O'Toole, L.J. Policy recommendations for multi-actor implementation: An assessment of the field. J. Public Policy 1986, 6, 181-210. [CrossRef]

44. Goggin, M.L.; Bowman, A.O.; Lester, J.; O'Toole, L.J.J. Implementation Theory and Practice: Toward a Third Generation; HarperCollins Publishers: New York, NY, USA, 1990.

45. Matland, R. Synthesising the implementation literature: The ambiguity-conflict model of policy implementation. J. Public Adm. Res. Theory 1995, 5, 145-174.

46. Rothstein, B. Just Institutions Matter: The Moral and Political Logic of the Universal Welfare State; Cambridge University Press: Cambridge, UK, 1998.

47. Peters, G.; Pierre, J. Handbook of Public Policy; Sage Publications: London, UK, 2006.

48. Milward, H.B.; Provan, K.G. Governing the Hollow State. J. Public Adm. Res. Theory 2000, 10, 359-379. [CrossRef]

49. United Nations. Public Governance Indicators: A Literature Review; United Nations: New York, NY, USA, 2007. 
50. Ostrom, E. Governing the Commons; Cambridge University Press: Cambridge, UK, 1990.

51. Bressers, H. Implementing sustainable development: How to know what works, where, when and how. In Governance for Sustainable Development: The Challenge of Adapting Form to Function; Lafferty, W.M., Ed.; Edward Elgar publishing: Cheltenham, UK, 2004; pp. 284-318.

52. Mohlakoana, N. Implementing the South African Free Basic Alternative Energy Policy; University of Twente: Enschede, The Netherlands, 2014.

53. Casiano, C.; Boer de, C. Symbolic implementation: Governance assessment of the water treatment plant policy in the Puebla's Alto Atoyac sub-basin. Int. J. Water Gov. 2015, 3, 1-24.

54. Owens, K.A.; Bressers, H. A Comparative Analysis of How Actors Implement: Testing the Contextual Interaction Theory in 48 Cases of Wetland Restoration. Comp. Policy Anal. Res. Pract. 2013, 15, 203-219. [CrossRef]

55. Bressers, H.; de Boer, C. Contextual interaction Theory for assessing water governance, policy and knowledge transfer. In Water Governance, Policy and Knowledge Transfer; Earthscan from Routledge: Oxford, UK, 2013; pp. 36-54.

56. Pemprov Jabar. Konsep Awal Pengembangan Metropolitan Bandung Raya. Available online: http:/ / metropolitan.jabarprov.go.id/sources / download/paper/6f79c-06-konsep-awal-pengembanganmetropolitan-bandung-raya_juni-2013_a22.pdf (accessed on 23 June 2017).

57. Bappeda. Penyusunan Review Masterplan Transportasi di Kota Bandung. Available online: http://lpse. bandung.go.id/eproc/lelang/view/4246260 (accessed on 23 June 2017).

58. BPS. Badan Pusat Statistik Kota Bandung. Available online: http://bandungkota.bps.go.id/subyek/ penduduk-2013 (accessed on 21 January 2015).

59. Bappenas. Panduan Penyusunan Rencana Aksi Daerah Pengurangan Emisi Gas Rumah Kaca. Available online: http://ranradgrk.bappenas.go.id/rangrk/admincms/downloads/publications/Pedoman_ pelaksanaan_rencana_aksi_penurunan_emisi_GRK.pdf (accessed on 23 June 2017).

60. Badan Pengelola Lingkungan Hidup (BPLH). Local Action Plan in Addressing Impact of Climate Change in Bandung City; Badan Pengelola Lingkungan Hidup (BPLH): Bandung, Indonesia, 2014.

61. Thambiran, T.; Diab, R.D. The case for integrated air quality and climate change policies. Environ. Sci. Policy 2011, 14, 1008-1017. [CrossRef]

62. Halsnaes, K.; Shukla, P. Sustainable development as a framework for developing country participation in international climate change policies. Mitig. Adapt. Strateg. Glob. Chang. 2008, 13, 105-130. [CrossRef]

63. Situmeang, H.H.; Lubis, S. M.; Prasetijo, D.; Sugiyanto, A.; Munzinger, P.; Rosenberg, A.; Laksmi, A.; Jinca, A.; Sakamoto, N.P.K.; Dore, C.; Sari, N.; Wulan, Y. C.; von Lupke, H.; Haeruman, H.; Guizol, P.; Faulwetter, M. Development of the Indonesian NAMAs Framework. Available online: https://www.transparencypartnership.net/sites/default/ files/indonesian-nama-framework-development-full-report.pdf (accessed on 23 June 2017).

64. Bulkeley, H.; Castán Broto, V.; Maassen, A. Low-carbon Transitions and the Reconfiguration of Urban Infrastructure. Urban Stud. 2014, 51, 1471-1486. [CrossRef]

65. Gunningham, N. Managing the energy trilemma: The case of Indonesia. Energy Policy 2013, 54, $184-193$. [CrossRef]

66. Nugroho, S.B. Co-Benefits Action Plan for Bandung; Institute for Global Environmental Strategies (IGES): Kanagawa, Japan, 2016.

67. Buendia, L.; Schmitz, D.; Munzinger, P.; Laksmi, A.; Hanik, U. Measurement Reporting Verification of GHG Inventory and RAN-GRK, RAD-GRK Mitigation Actions (NAMA); EUMRVCB Project and PAKLIM GIZ Project: Jakarta, Indonesia, 2012.

(C) 2017 by the authors. Licensee MDPI, Basel, Switzerland. This article is an open access article distributed under the terms and conditions of the Creative Commons Attribution (CC BY) license (http:/ / creativecommons.org/licenses/by/4.0/). 